Genome sequencing

\section{More actors apply for parts}

Bethesda, Maryland

THE US National Institutes of Health (NIH) last week sponsored the latest instalment of the human genome mapping and/or sequencing debate, and once again no clear winners emerged. But there has been progress. The initial polarization of opinions has given way to a more constructive consensus that some concerted effort can begin without rending the fabric of biological science.

Like many other institutions, both public and private, NIH are now grappling with the question of what their role should be in any sequencing or mapping project. Last week's discussions were held at the meeting of the advisory committee to NIH director James Wyngaarden. Given budgetary lead times, any major financial commitment from NIH could not come before the 1989 fiscal year.

At the heart of the debate is the question of the value of knowing the sequence of the entire genome. David Baltimore of the Whitehead Institute argues that a free gift of the sequence would be welcome, but not having it was no great hindrance. If asked to rate the project, he would place it in the category of worthy projects that could be funded if unlimited resources were available. As that is not the case, Baltimore would prefer to see funds spent on smaller projects with more immediate promise of interesting results. Baltimore believes that a huge, low-priority project would be "ruinous" and could easily become a political target. David Botstein of the Massachusetts Institute of Technology nized. (DoE) and NIH.

argues that a "pay-as-you-go" approach would provide sequence data in a piecemeal fashion, but the emphasis would be on the 3 per cent of the genome thought to encode protein. Botstein questions the need "to sequence everything to get to the 3 per cent". But Renato Dulbecco of the Salk Institute believes that only a complete sequence will reveal the functional significance of how the chromosome is orga-

If pursuing a sequence remains a contentious area, there is fairly wide support for making both a genetic and a physical map of the genome. Most concede that a complete physical map ought to precede any full-scale sequencing. But efforts so far in both sequencing and mapping have shown a need for better data handling and organization procedures. Wyngaarden believes that information organization and communication is the area most urgently needing attention even if sequencing and mapping efforts never get any bigger then they are now. Work so far is proving nearly overwhelming for GenBank, the DNA sequence database supported by the Department of Energy

George Cahill of the Howard Hughes Medical Institute told the NIH meeting that coordinating emerging databases was rated a top priority by participants in meeting on the human genome held at his institute last July (see Nature 322, 397; 1986). Hughes is currently supporting work by Frank Ruddle at Yale University on a human gene map database, and

\title{
Doubts about Department of Energy
}

\section{Washington}

Although the Department of Energy's interest in a human genome sequence or mapping project came as a surprise to some, it is not uncharacteristic of the department's work. In addition to its role in GenBank, two Energy Department laboratories have constructed a chromosomespecific DNA library. But some prominent scientists have doubts about the level of biological talent at Department of Energy laboratories.

Their concern arises from contamination problems with the department's chromosome-specific libraries. In order to sort the larger human chromosomes, it was necessary to construct hybrids using chinese hamster DNA. This inevitably leads to some contamination, because hamster and human DNA cross-react. But some argue that the amount of contamination makes the libraries of questionable value.

Lee Hood of the California Institute of Technology says he is "appalled and de- pressed" at the efforts of Los Alamos and Livermore National laboratories to make the libraries. Larry Deaven of Los Alamos National Laboratory, who co-directed the project, does not agree that the work was improperly done. He says the contamination problem is closer to $10-15$ per cent, although for chromosome 11 he admits as much as $40-50$ per cent hamster DNA is present. But Deaven says he would not make any significant change in procedures. Tom Shows of Roswell Park Memorial Institute and a member of Deaven's scientific advisory panel agrees that the Energy department's effort was as good as existing technology permitted. By taking on a project for wide-scale distribution more than 1,000 libraries have been handed out - Shows says the effort faced a difficult task in maintaining purity. But Shows' data indicate the contamination of the chromosome 11 library is closer to 60 per cent, a discouragingly high figure.

Joseph Palca hopes to link that database with Victor McKusick's Mendelian Inheritance in Man recently available on line. Next year, Cahill hopes to see Jackson Laboratory's mouse gene data linked with the human databases.

The need for a well-organized information exchange system is felt keenly in Europe. Lennart Philipson, directorgeneral of the European Molecular Biology Laboratory (EMBL), argues that a forward thinking plan is needed to make full use of the information that will be pouring in from laboratories in Europe, Japan and the United States. That such an exchange system is possible is demonstrated by EMBL's participation in GenBank. EMBL and NIH will hold a joint meeting to discuss standardization next February.

Besides storing sequence and map data, there is a need to make sense of it. Both the National Science Foundation and DoE are supporting efforts to develop new algorithms for handling such data.

Although NIH seems a logical government agency to be interested in the human genome, other agencies such as the National Science Foundation, DoE and even the Department of Defense have shown interest in elements of a mapping or sequencing project.

Discussions have begun informally on how the agencies might coordinate their efforts, but formal negotiations have yet to begin. Jealousy among the agencies invites speculation that international cooperation is more likely than interagency cooperation.

DoE kicked off this year's debate about the human genome with a meeting last March (see Nature 321, 371; 1986). Charles DeLisi, director of DoE's Office of Health and Environmental Research, insists it was never his department's intention to sequence the genome, but many came away with that impression after the March meeting. DeLisi says his agency will continue to support activities directed at an ordered set of overlapping cosmids, improved database management and automation of sequencing and cloning technologies. Of the $\$ 10-\$ 20$ million the department plans to spend over the next five years, one quarter will be available to universities and others outside the department.

At the start of the year, says George Palade of Yale University, biologists were divided into two camps on the question of sequencing the human genome; those who said "do it now", and those who said "don't do it". Now, Palade sees a consensus forming, with ideas surfacing on how to achieve what is admittedly a desirable goal.

The issue facing NIH, says Wyngaarden, is "should we devote resources to sequencing the human genome even if it means limiting other research activities?" Joseph Palca 